\title{
Treatment Options in Oligometastatic Disease: Stereotactic Body Radiation Therapy - Focus on Colorectal Cancer
}

\author{
Aaron T. Wild Yoshiya Yamada \\ Department of Radiation Oncology, Memorial Sloan Kettering Cancer Center, New York, NY, USA
}

\section{Keywords}

Stereotactic body radiation therapy, SBRT .

Stereotactic ablative body radiotherapy - Oligometastasis .

Colorectal cancer - Gastrointestinal cancer

\section{Summary}

Background: Improvements in systemic therapy for metastatic colorectal cancer (CRC) have markedly extended survival, rendering local control of metastases to critical organs of increasing importance, especially in the oligometastatic setting where the disease may not yet have acquired the ability to widely disseminate. While surgical resection remains the gold standard for oligometastases in many organs, stereotactic body radiation therapy (SBRT) presents a non-invasive alternative for achieving local control. Methods: A literature review was performed to identify and summarize the findings of key prospective and retrospective studies that have shaped the field of SBRT for oligometastases to the lung, liver, and spine with a focus on oligometastases from CRC in particular. Results: Modern dose-escalated SBRT regimens can achieve 1-year local control rates of $77-100 \%$, $90-100 \%$, and $81-95 \%$ for oligometastases involving the lung, liver, and spine, respectively. Rates of grade 3 or greater toxicity with contemporary SBRT techniques are consistently low at $<10 \%$ in the lung, $<5 \%$ in the liver, and $<2 \% / 8 \%$ for neurologic/non-neurologic toxicity in the spine, respectively. Conclusion: SBRT appears safe and effective for treating oligometastases involving the lung, liver, and spine. Randomized trials comparing SBRT to surgical resection and other local therapeutic modalities for the treatment of CRC oligometastases bear consideration.

(C) 2017 S. Karger GmbH, Freiburg

\section{Introduction}

Up to half of patients with colorectal cancer (CRC) will develop metastatic disease [1], a condition traditionally managed with palliative chemotherapy and best supportive care resulting in dismal 5 -year survival rates of less than 5\% [2]. However, the emergence of new chemotherapeutic agents and targeted biologics since the late 1990s has produced substantial gains in overall and progressionfree survival in patients with metastatic CRC, including extension of median survival to approximately 29 months [3, 4]. In light of these advances, guidelines from the National Comprehensive Cancer Network now recommend aggressive local management with curative intent surgery for resectable oligometastases in candidates with metastatic involvement limited to the lung and liver [5].

In the current article, the role of stereotactic body radiation therapy (SBRT) in the setting of oligometastatic disease will be explored with a focus on CRC. Comparison to other local treatment modalities will be provided where data is available. We will examine the safety and efficacy of SBRT in the three anatomic settings where it is most commonly utilized - namely, the lung, the liver, and the spine. Some historical perspective on the specific associated challenges in regard to normal tissue complications will be offered.

\section{Technical Aspects of Stereotactic Body Radiation Therapy}

SBRT can be defined as a technique for delivering high doses of radiation to extracranial lesions in a low number of treatments, typically 1-5 fractions. The crux of what distinguishes SBRT from conventionally fractionated radiation therapy is its capacity for an ablative effect due to the use of very large doses per fraction. While such an effect is desirable in malignant tissue, it can be detrimental to surrounding normal tissue. Safe administration of SBRT therefore requires a high degree of precision.

\section{KARGER}

() 2017 S. Karger GmbH, Freiburg

Fax +497614520714
Yoshiya Yamada, MD, FRCPC 
Such precision is achieved through several interrelated means. Sophisticated planning software is required to achieve a steep isodose gradient with rapid dose falloff outside the target volume in order to spare surrounding normal tissue. Several static beam angles, i.e. up to $10-12$, or movement of the beam in a continuous arc (volumetric modulated arc therapy) can be used to achieve optimal dose distribution, as opposed to conventional three-dimensional conformal radiation therapy (3DCRT) where four or fewer beam angles are employed.

External immobilization devices are important for patients to maintain the correct position in three-dimensional space and to minimize patient and target lesion motion during treatment delivery [6].

High-resolution imaging, fusion of multiple imaging modalities, and methodology are useful to reduce motion and uncertainty in target position during treatment. The latter has historically been a major barrier for using high-dose radiation outside of the brain. However, substantial progress has been made with the advent of onboard image guidance where the linear accelerator generating the radiation beam is equipped with an imaging system that can monitor tumor location. Accurate target localization can be accomplished by three-dimensional volumetric imaging with in-room computed tomography (CT) [7]. Alternatively, the insertion of metal fiducial markers or radiofrequency transponders into the tumor can allow for real-time tracking with on-board planar imaging. Accounting for target movement is critical, especially at anatomic sites in perpetual physiologic motion, such as the lung and liver. This can be accomplished by using infrared chest wall tracking linked either to X-ray images taken during treatment or to predictive algorithms modeling respiratory motion [8]. More simplistically, target motion can be limited using inflatable abdominal compression devices [9] and respiratory gating with breath-hold techniques [10]. This review article will trace the clinical data leading to derivation of modern SBRT regimens used for lesions in the lung, liver, and spine.

\section{Stereotactic Body Radiation Therapy for Lung Oligometastases}

Lung metastases develop in $5-15 \%$ of CRC patients [11]. Although prospective data regarding the benefit of pulmonary metastasectomy are lacking, a meta-analysis of 25 studies involving 2,925 patients demonstrated 5-year overall survival rates of 27-68\% [12]. While most patients progress distantly, local recurrence following pulmonary metastasectomy occurs at a rate of 19.5-28\% [13-15], often in spite of negative margins [16].

Most early data were derived from heterogeneous series including metastases from diverse primary histologies as well as primary lung tumors. More recent series provide a focus on lung oligometastases specifically from CRC. As summarized in table 1, these studies consistently demonstrate SBRT for pulmonary oligometastases to have a high degree of safety with grade 3 toxicity rates of less than $10 \%$ and in most series less than $5 \%$; grade 4 or greater toxicity is rare with no cases documented in the reports described in table 1 [17-27]. Efficacy in providing long-term control of irra- diated pulmonary metastases from CRC appears to vary from 67$94 \%$, in part based on dose and fractionation. These findings appear similar to historical rates of local recurrence for pulmonary oligometastases from CRC following surgical metastasectomy, which range from $19.5-28 \%$ [13-15]. Some of the earlier studies delineated above demonstrate decreased local control for pulmonary oligometastases from CRC as opposed to other primary tumors. Possible reasons for these observations include the common presence of satellite tumor cells around CRC metastases as well as a higher ratio of hypoxic cells in CRC metastases as opposed to other tumor types with consequent reduction in radiosensitivity [28]. Nonetheless, studies published within the past 3 years employing modern thoracic SBRT techniques and escalated doses with a biological effective dose (BED) of at least 94 Gy consistently report excellent local control rates of greater than $90 \%$ specifically for colorectal oligometastases.

Survival outcomes following SBRT for pulmonary oligometastases from CRC are encouraging. In the studies listed in table 1 where the relevant data were available, overall survival at 1,2 , and 5 years ranged from $83-100 \%, 43-76 \%$, and 39-49\%, respectively. Despite the fact that SBRT patients are typically older, unfit for surgery, and have greater medical comorbidity, these outcomes are within range of those for surgical metastasectomy, which is associated with 5-year overall survival rates of $27-68 \%$ [12]. A group from the Netherlands compared 68 patients treated with pulmonary metastasectomy to 42 patients treated with SBRT for up to 5 pulmonary oligometastases [29]. SBRT consisted of 60 Gy in 3-8 fractions (BED 105-180 Gy). A large number of patients in both the metastasectomy and SBRT groups (57 and 74\%, respectively) had CRC as their primary tumor. The SBRT group had worse baseline prognostic factors, including significantly older age and a shorter metastasis-free interval. Despite these biases, rates of overall survival at 1,3 , and 5 years were similar for metastasectomy and SBRT at 87,62 , and $41 \%$ versus 98,60 , and $49 \%$, respectively. At 2 years, local control rates were similar at $90 \%$ for metastasectomy and $94 \%$ for SBRT. While prospective head-to-head studies are needed, these retrospective data suggest that survival is no worse after SBRT compared to metastasectomy.

Moreover, local control has not yet been shown to increase survival in any surgical or SBRT series [30]. This highlights the need for additional prospective data with standardized patient inclusion criteria for both pulmonary metastasectomy and SBRT. The PulMICC trial (NCT01106261), which is currently recruiting in the UK, will provide data on the feasibility of enrolling adequate numbers of CRC patients for a phase III randomized trial with power to identify survival differences between pulmonary metastasectomy and active surveillance.

\section{Stereotactic Body Radiation Therapy for Liver Oligometastases}

The liver represents the most common site of CRC metastasis. The survival of patients with untreated hepatic metastases from 


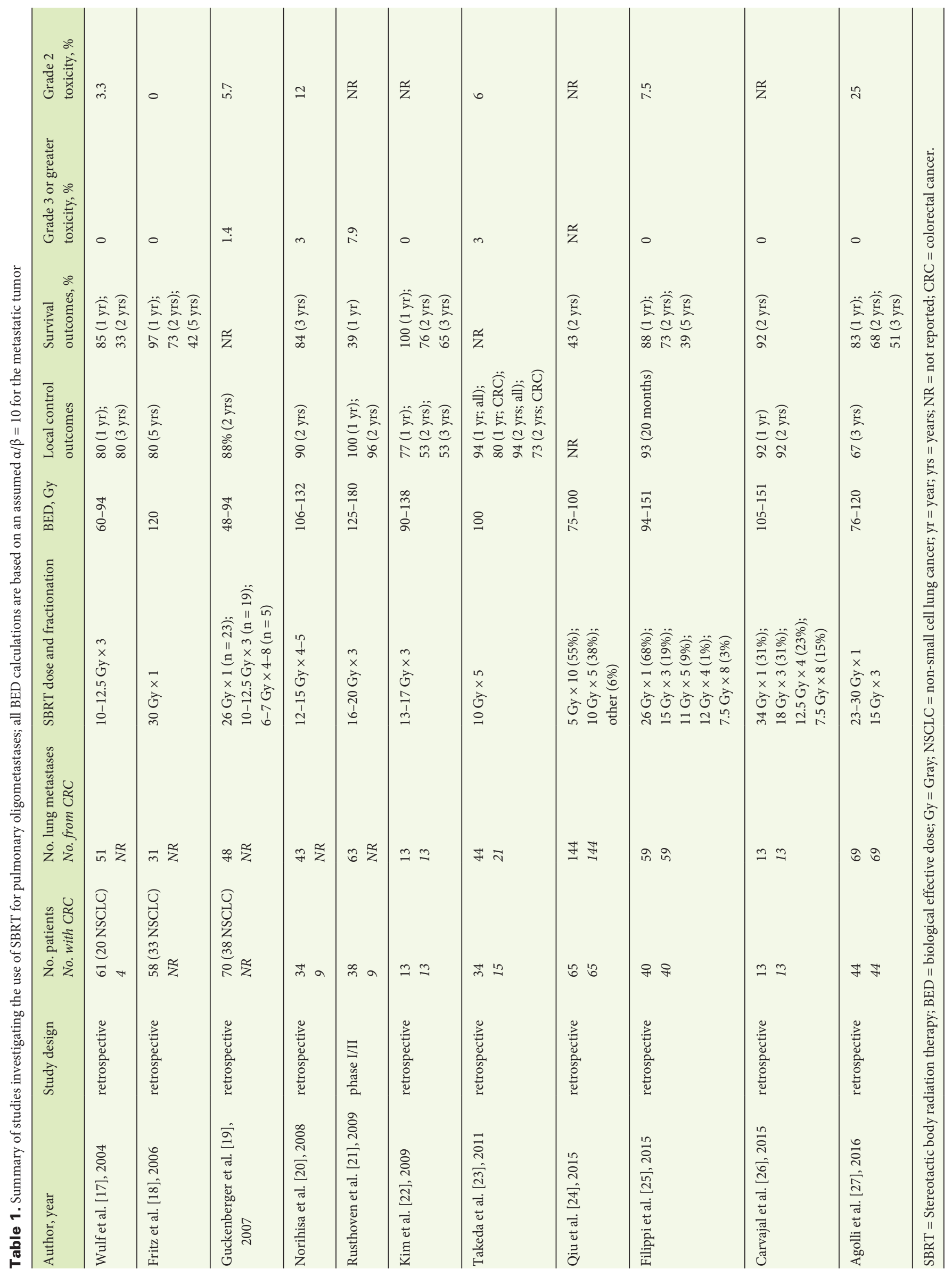




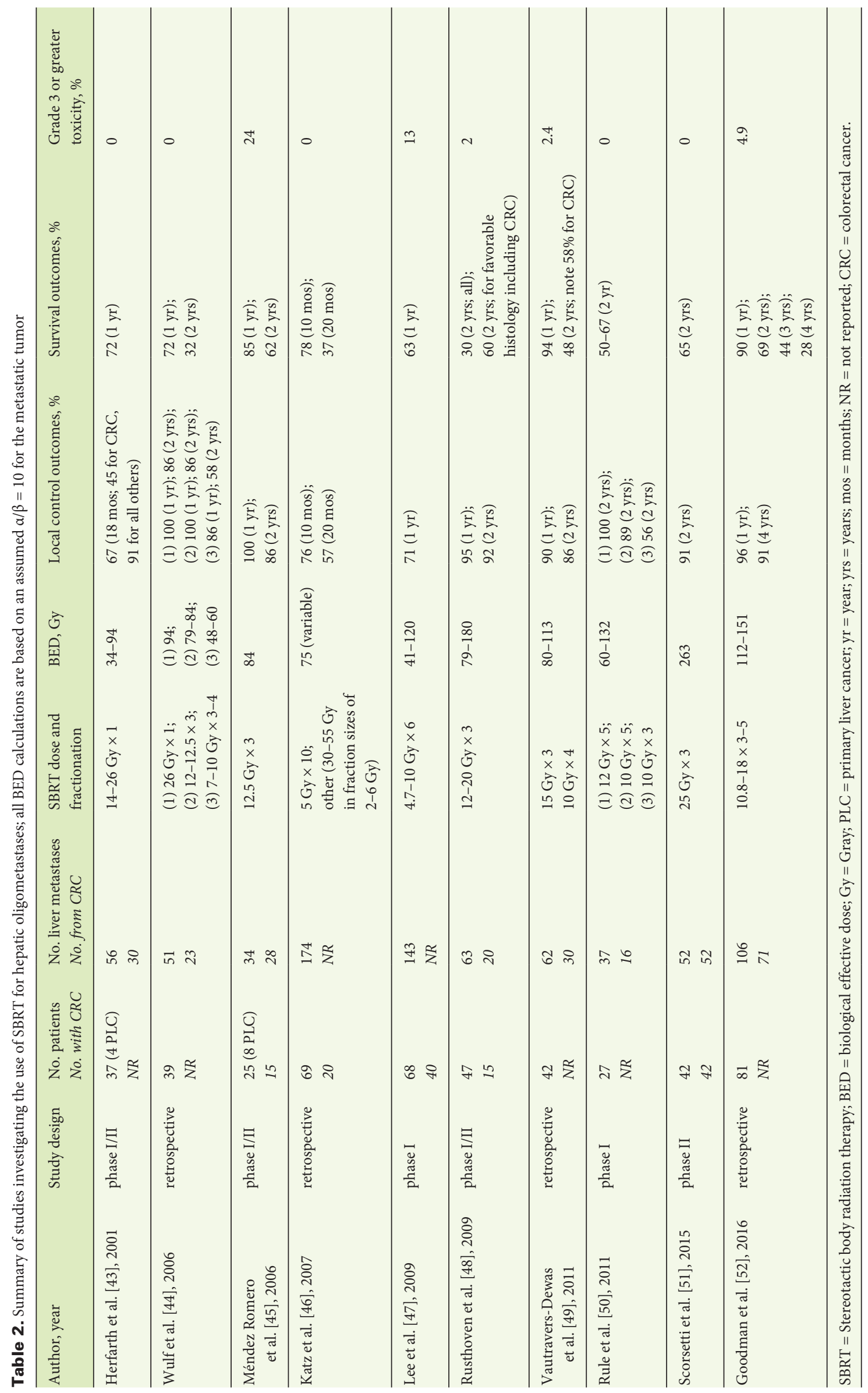


CRC is dismal at approximately $20-30 \%$ at 1 year, $8-10 \%$ at 2 years, and $0-5 \%$ at 5 years $[31,32]$. In three large series, overall survival for patients with resectable liver-limited metastases was approximately $30-40 \%$ at 5 years and $22-24 \%$ at 10 years [33-35]. The efficacy of liver metastasectomy in CRC is now well established with more modern series reporting 5-year survival rates as high as $58 \%[36,37]$ and - in cases of a solitary liver metastasis up to $71 \%$ [38] with some cures.

The findings above provide a strong rationale for pursuing aggressive local management of liver-only metastases in well selected CRC patients. Unfortunately, liver metastases from CRC prove to be unresectable in $40-90 \%$ of patients $[39,40]$. Radiofrequency ablation (RFA) represents one alternative, though it is limited by tumor size and anatomic location, including contraindication for metastases located nearby large vessels or the diaphragm.

Historically, there has been a bias against radiotherapy for malignant disease of the liver because of low tolerance of the whole liver to radiation. The most serious complication of external beam radiation therapy (EBRT) to the liver is radiation-induced liver disease (RILD). RILD is a clinical syndrome of hepatomegaly, ascites, elevated liver enzymes (most notably alkaline phosphatase), and eventually jaundice that can occur 2 weeks to 4 months following EBRT. The pathophysiology resembles Budd-Chiari syndrome and veno-occlusive disease.

In the pilot study for whole-liver EBRT, i.e. RTOG 76-05, 103 patients with solid tumor hepatic metastases were treated with a variety of dose regimens ranging from $21 \mathrm{~Gy}$ in 3 fractions to 30.4 Gy in 19 fractions [41]. No hepatic toxicity was observed, leading to a subsequent dose escalation study, RTOG 84-05 [42]. 173 patients with liver metastases from a gastrointestinal primary cancer (75\% CRC) were treated with whole-liver EBRT. The dose was escalated from 27 to 30 to 33 Gy in 1.5-Gy twice daily fractions. RILD was observed in 5 of 51 patients at the 33-Gy dose level, while no liver injury was observed at the 27- or 30-Gy dose levels. Median survival was not significantly different between the 3 groups at 4.2 , 4.2 , and 4.3 months, respectively. The authors concluded that 33 Gy was an unsafe dose to the whole liver without any associated benefit in clinical outcomes.

Efficacy of SBRT appears, at the least, quite promising for liver metastases from CRC. Multiple studies in table 2 [43-52] show the importance of dose escalation in using SBRT to treat liver metastases $[43,44,48,50,51]$. High doses appear to be particularly important in treating CRC metastases; a recent study using a 10-gene assay to assess radiosensitivity of hepatic metastases from different primary histologies demonstrated CRC metastases to be more radioresistent than breast adenocarcinoma, lung adenocarcinoma, and anal squamous cell cancer [53]. The excellent local control observed in recent series, however, suggests that modern SBRT doses have surpassed the threshold needed to control liver metastases from CRC.

Surgery remains the gold standard for hepatic oligometastases. The lesions treated in the studies of SBRT included in table 2 were considered unresectable, suggesting that they generally tended to be larger, multiple in number, or in critical anatomic regions; alternatively, patients may have been unfavorable candidates for sur- gery due to medical comorbidity, insufficient hepatic reserve, or presence of extrahepatic metastases. In spite of these baseline disadvantages compared to lesions undergoing hepatic resection, local control outcomes for SBRT approach those of surgery at most available time points. Local control ranges from $71-100 \%$ at 1 year and $57-100 \%$ at 2 years in the data are presented in table 2 ; however, these data include suboptimal doses used in the early portions of dose escalation trials. When one considers only dose-escalated regimens [45, 48-52], 1-year and 2-year local control range from $90-100 \%$ and $81-100 \%$, respectively. A major limitation of the current outcomes data for SBRT is the lack of long-term prospective follow-up; however, a large retrospective review shows durable local control of $91 \%$ at 4 years [52]. In general, these local control outcomes are comparable to reported surgical local control rates of $88-95 \%$ at 3 years $[38,54]$ and appear substantially better than local control rates of $32-76 \%$ at 2 years with RFA $[55,56]$. Overall survival rates for patients undergoing SBRT range from $63-94 \%$ at 1 year and $32-83 \%$ at 2 years in the studies presented, with 4 -year overall survival available in one retrospective study at $28 \%$.

\section{Stereotactic Body Radiation Therapy for Spine Oligometastases}

Bone metastases are rare in patients with CRC with an overall incidence of only $5-11 \%[57,58]$. In series of patients presenting with metastatic epidural spinal cord compression (MESCC), metastases from CRC account for only $1.5-4.7 \%$ of cases [59, 60].

The majority of patients with MESCC have historically been treated with palliative conventional EBRT alone. Given the inherent radioresistance of certain malignancies, including CRC [53], renal cell carcinoma, and melanoma $[61,62]$, this BED is unlikely to provide durable long-term local control. Retrospective series suggest that the median time to recurrence following conventionally fractionated EBRT to the spine is approximately 6 months [63]. Attempts to increase the dose of conventionally fractionated EBRT for relatively radioresistant histologies are limited by the dose tolerance of the spinal cord and have not shown significant improvements in local control [64].

SBRT is a particularly attractive option for metastatic lesions in close proximity to the spinal cord as it can achieve precise delivery of high dose radiation to the target with sharp dose gradients to avoid exceeding dose tolerance of the nearby spinal cord. Selected studies that helped to establish the safety and efficacy of both hypofractionated and single-fraction SBRT for spine oligometastases are summarized in table 3 [65-69]. Of note, only the study performed by Yamada et al. [66] included patients with MESCC (although patients with high-grade MESCC were excluded) while the other 4 studies excluded patients with any degree of MESCC.

These reports provide strong support for the use of SBRT for the challenging clinical situation of oligometastases involving the spine. The technique appears safe with rare grade 3 or greater neurologic toxicity at $0-1.6 \%$ and grade 3 non-neurologic toxicity rates of $8 \%$ or less. Efficacy appears high with local control rates of $81-$ 
Table 3. Summary of studies investigating the use of SBRT for spine oligometastases; all BED calculations are based on an assumed $\alpha / \beta=10$ for the metastatic tumor

\begin{tabular}{|c|c|c|c|c|c|c|c|c|}
\hline Author, year & Study design & $\begin{array}{l}\text { No. patients } \\
\text { No. with CRC }\end{array}$ & $\begin{array}{l}\text { No. spine } \\
\text { metastases } \\
\text { No. from CRC }\end{array}$ & $\begin{array}{l}\text { SBRT dose and } \\
\text { fractionation }\end{array}$ & $\begin{array}{l}\text { BED, } \\
\text { Gy }\end{array}$ & $\begin{array}{l}\text { Local control } \\
\text { outcomes, } \%\end{array}$ & $\begin{array}{l}\text { Survival } \\
\text { outcomes, \% }\end{array}$ & $\begin{array}{l}\text { Grade } 3 \text { or greater } \\
\text { toxicity, } \%\end{array}$ \\
\hline $\begin{array}{l}\text { Chang et al. } \\
\text { [65], } 2004\end{array}$ & phase I/II & $\begin{array}{r}63 \\
1\end{array}$ & $\begin{array}{r}74 \\
1\end{array}$ & $\begin{array}{l}9 \mathrm{~Gy} \times 3 \\
6 \mathrm{~Gy} \times 5\end{array}$ & $48-51$ & $\begin{array}{l}84(1 \mathrm{yr}) \\
77 \text { ( } 2 \text { yrs })\end{array}$ & 70 (1 yr) & 4.8 \\
\hline $\begin{array}{r}\text { Yamada et al. } \\
{[66], 2008}\end{array}$ & retrospective & $\begin{array}{l}93 \\
11\end{array}$ & $\begin{array}{l}103 \\
N R\end{array}$ & $18-24 \mathrm{~Gy} \times 1$ & $50-81$ & $\begin{array}{l}90(15 \text { mos; } \\
95 \text { for } 24 \text { Gy vs. } \\
81 \text { for } 18-23 \mathrm{~Gy})\end{array}$ & 36 (45 mos) & 0 \\
\hline $\begin{array}{l}\text { Amdur et al. } \\
\text { [67], } 2009\end{array}$ & phase II & $\begin{array}{r}21 \\
1\end{array}$ & $\begin{array}{r}25 \\
1\end{array}$ & $15 \mathrm{~Gy} \times 1$ & 38 & 95 (8 mos) & 25 (1 yr) & 0 \\
\hline $\begin{array}{l}\text { Wang et al. } \\
\text { [68], } 2012\end{array}$ & phase I/II & $\begin{array}{r}149 \\
6\end{array}$ & $\begin{array}{l}166 \\
N R\end{array}$ & $9-10 \mathrm{~Gy} \times 3$ & $51-60$ & $\begin{array}{l}81 \text { ( } 1 \text { yr); } \\
73 \text { (2 yrs) }\end{array}$ & $\begin{array}{l}72 \text { (1yr); } \\
49 \text { ( } 2 \text { yrs) }\end{array}$ & 8 \\
\hline $\begin{array}{l}\text { Garg et al. } \\
\qquad[69], 2012\end{array}$ & phase I/II & $\begin{array}{r}61 \\
N R\end{array}$ & $\begin{array}{r}63 \\
N R\end{array}$ & $16-24 \mathrm{~Gy} \times 1$ & $42-81$ & 88 (18 mos) & $64(18 \mathrm{mos})$ & 3.3 \\
\hline
\end{tabular}

$\mathrm{SBRT}=$ Stereotactic body radiation therapy $\mathrm{BED}=$ biological effective dose Gy = Gray; yr = year; yrs = years; mos = months; NR = not reported;

$\mathrm{CRC}=$ colorectal cancer.

$90 \%$ at 1 year despite the fact that multiple series included spine metastases that had progressed after prior conventional EBRT [6568]. When dose can be escalated to $24 \mathrm{~Gy}$ in a single fraction, local control rates at 1 year can reach 95\% [66]. Moreover, the length of survival following spinal SBRT was substantial in many of the prospective trials in table 3 at median 23-30 months. The observed longevity following SBRT suggests that effective local therapy to achieve long-term local control is worthwhile for spine metastases, where progression could drastically reduce mobility, neurologic function, and quality of life.

In cases of high-grade MESCC, upfront spinal cord decompression surgery is often needed to remove epidural disease in near or direct contact with the cord $[70,71]$. The use of postoperative SBRT to the region at risk and any residual osseous or epidural disease can allow for safer, less radical surgery and achieve high rates of local control. Laufer et al. [72] reported a series of 186 patients (8\% CRC) with MESCC treated with surgical decompression followed by SBRT given at 3 dose levels: 24 Gy in a single fraction (BED 81.6 Gy), 24-30 Gy in 3 fractions (BED 43.2-60 Gy), or 18-36 Gy in 5 or 6 fractions (BED 24.5-57.6 Gy). Local control for all patients was $83.6 \%$ at 1 year. Patients receiving higher BED regimens of 24 Gy in a single fraction or 24-30 Gy in 3 fractions demonstrated local control of 91 and $95.9 \%$ at 1 year, respectively, versus $77 \%$ in patients receiving $18-36$ Gy in 5 or 6 fractions. Local control was not found to be associated with primary tumor histology. No neurologic toxicity occurred due to SBRT; 4 patients underwent reoperation due to hardware failure.

The durability of local control and symptom palliation with SBRT appears markedly superior to conventional EBRT when com- parison is made to historical controls. RTOG 06-31 (NCT00922974) is an ongoing randomized trial that will seek to address this question in a standardized fashion. Patients with significant pain from spine metastases and no history of prior radiation or surgery to the region of interest will be randomized to $16 \mathrm{~Gy}$ in a single fraction using SBRT versus delivery of $8 \mathrm{~Gy}$ in a single fraction with conventional radiation.

\section{Conclusion and Future Directions}

Advances in systemic therapy for CRC have markedly extended the survival of patients with metastatic disease, rendering effective local therapy of increasing importance. This is especially true in the oligometastatic setting where malignant cells may not yet have acquired widespread metastatic potential. Despite the traditional radioresistance associated with CRC, modern dose-escalated SBRT regimens are able to overcome this and achieve high rates of local control. While surgery remains the gold standard for resectable oligometastases from CRC, the local control outcomes in recent reports of SBRT closely approach those of surgery. These results in combination with the low morbidity associated with SBRT are compelling for consideration of randomized trials comparing SBRT to resection.

\section{Disclosure Statement}

No conflicts of interest. 


\section{References}

1 Wang CC, Li J: An update on chemotherapy of colorectal liver metastases. World J Gastroenterol 2012;18: 25-33.

2 Poon MA, O'Connell MJ, Moertel CG, Wieand HS, Cullinan SA, Everson LK, Krook JE, Mailliard JA, Laurie JA, Tschetter LK, Wiesenfeld M: Biochemical modulation of fluorouracil: evidence of significant improvement of survival and quality of life in patients with advanced colorectal carcinoma. J Clin Oncol 1989;7:1407-1418.

3 Giantonio BJ, Levy DE, O'dwyer PJ, Meropol NJ, Catalano PJ, Benson AB 3rd; Eastern Cooperative Oncology Group: A phase II study of high-dose bevacizumab in combination with irinotecan, 5-fluorouracil, leucovorin, as initial therapy for advanced colorectal cancer: results from the Eastern Cooperative Oncology Group study E2200. Ann Oncol 2006;17:1399-1403.

4 Cunningham D, Humblet Y, Siena S, Khayat D, Bleiberg H, Santoro A, Bets D, Mueser M, Harstrick A, Verslype C, Chau I, Van Cutsem E: Cetuximab monotherapy and cetuximab plus irinotecan in irinotecanrefractory metastatic colorectal cancer. N Engl J Med 2004;351:337-345

5 Benson AB, Grem JL, Saltz L, Bekaii-Saab T, Hunt S, Sharma S, Chan E, Kamel A, Skibber JM, Chen Y: NCCN Clinical Practice Guideline in Oncology Web Site. Colon Cancer: National Comprehensive Cancer Network. Version 3. 2013.

6 Rubio C, Morera R, Hernando O, Leroy T, Lartigau SE: Extracranial stereotactic body radiotherapy. Review of main SBRT features and indications in primary tumors. Rep Pract Oncol Radiother 2013;18:387-396.

7 Wang L, Hayes S, Paskalev K, Jin L, Buyyounouski MK, Ma CC, Feigenberg S: Dosimetric comparison of stereotactic body radiotherapy using $4 \mathrm{D} \mathrm{CT}$ and multiphase CT images for treatment planning of lung cancer: evaluation of the impact on daily dose coverage. Radiother Oncol 2009;91:314-324.

8 van der Voort, van Zyp NC, Prévost JB, Hoogeman MS, Praag J, van der Holt B, Levendag PC, van Klaveren RJ, Pattynama P, Nuyttens JJ: Stereotactic radiotherapy with real-time tumor tracking for nonsmall cell lung cancer: clinical outcome. Radiother Oncol 2009;91:296-300.

9 McGarry RC, Papiez L, Williams M, Whitford T, Timmerman RD: Stereotactic body radiation therapy of early-stage non-small-cell lung carcinoma: phase I study. Int J Radiat Oncol Biol Phys 2005;63:1010-1015.

10 Onishi H, Shirato H, Nagata Y, Hiraoka M, Fujino M, Gomi K, Niibe Y, Karasawa K, Hayakawa K, Takai Y, Kimura T, Takeda A, Ouchi A, Hareyama M, Kokubo M, Hara R, Itami J, Yamada K, Araki T: Hypofractionated stereotactic radiotherapy (HypoFXSRT) for stage I non-small cell lung cancer: updated results of $257 \mathrm{pa}-$ tients in a Japanese multi-institutional study. J Thorac Oncol 2007;2(suppl 3):S94-100.

11 Gonzalez M, Ris HB, Krueger T, Gervaz P: Colorectal cancer and thoracic surgeons: close encounters of the third kind. Expert Rev Anticancer Ther 2012;12:495503

12 Gonzalez M, Poncet A, Combescure C, Robert J, Ris $\mathrm{HB}$, Gervaz P: Risk factors for survival after lung metastasectomy in colorectal cancer patients: a systematic review and meta-analysis. Ann Surg Oncol 2013;20: 572-579.

13 Welter S, Jacobs J, Krbek T, Krebs B, Stamatis G: Longterm survival after repeated resection of pulmonary metastases from colorectal cancer. Ann Thorac Surg 2007;84:203-210.
14 De Giacomo T, Rendina EA, Venuta F, Ciccone AM, Coloni GF: Thoracoscopic resection of solitary lung metastases from colorectal cancer is a viable therapeutic option. Chest 1999;115:1441-1443.

15 Welter S, Theegarten D, Trarbach T, Maletzki F, Stamatis G, Tötsch M: Safety distance in the resection of colorectal lung metastases: a prospective evaluation of satellite tumor cells with immunohistochemistry. J Thorac Cardiovasc Surg 2011;141:1218-1222.

16 Shiono S, Ishii G, Nagai K, Yoshida J, Nishimura M, Murata Y, Tsuta K, Kim YH, Nishiwaki Y, Kodama T, Iwasaki M, Ochiai A: Predictive factors for local recurrence of resected colorectal lung metastases. Ann Thorac Surg 2005;80:1040-1045.

17 Wulf J, Haedinger U, Oppitz U, Thiele W, Mueller G, Flentje M: Stereotactic radiotherapy for primary lung cancer and pulmonary metastases: a noninvasive treatment approach in medically inoperable patients. Int J Radiat Oncol Biol Phys 2004;60:186-196.

18 Fritz P, Kraus HJ, Mühlnickel W, Hammer U, Dölken W, Engel-Riedel W, Chemaissani A, Stoelben E: Stereotactic, single-dose irradiation of stage I non-small cell lung cancer and lung metastases. Radiat Oncol 2006; $1: 30$.

19 Guckenberger M, Heilman K, Wulf J, Mueller G, Beckmann G, Flentje M: Pulmonary injury and tumor response after stereotactic body radiotherapy (SBRT): results of a serial follow-up CT study. Radiother Oncol 2007;85:435-442.

20 Norihisa Y, Nagata Y, Takayama K, Matsuo Y, Sakamoto T, Sakamoto M, Mizowaki T, Yano S, Hiraoka M: Stereotactic body radiotherapy for oligometastatic lung tumors. Int J Radiat Oncol Biol Phys 2008;72: 398-403.

21 Rusthoven KE, Kavanagh BD, Burri SH, Chen C, Cardenes H, Chidel MA, Pugh TJ, Kane M, Gaspar LE, Schefter TE: Multi-institutional phase I/II trial of stereotactic body radiation therapy for lung metastases. J Clin Oncol 2009;27:1579-1584.

22 Kim MS, Yoo SY, Cho CK, Yoo HJ, Choi CW, Seo YS, Kang JK, Lee DH, Hwang DY, Moon SM, Kim MS, Kang HJ, Kim YH: Stereotactic body radiation therapy using three fractions for isolated lung recurrence from colorectal cancer. Oncology 2009;76:212-219.

23 Takeda A, Kunieda E, Ohashi T, Aoki Y, Koike N, Takeda T: Stereotactic body radiotherapy (SBRT) for oligometastatic lung tumors from colorectal cancer and other primary cancers in comparison with primary lung cancer. Radiother Oncol 2011;101:255-259.

24 Qiu H, Katz AW, Chowdhry AK, Usuki KY, Singh DP, Metcalfe S, Cheruvu P, Chen Y, Okunieff P, Milano MT: Stereotactic body radiotherapy for lung metastases from colorectal cancer: prognostic factors for disease control and survival. Am J Clin Oncol 2015;DOI: 10.1097/COC.0000000000000220.

25 Filippi AR, Badellino S, Ceccarelli M, Guarneri A, Franco P, Monagheddu C, Spadi R, Ragona R, Racca P, Ricardi U: Stereotactic ablative radiation therapy as first local therapy for lung oligometastases from colorectal cancer: a single-institution cohort study. Int J Radiat Oncol Biol Phys 2015;91:524-529.

26 Carvajal C, Navarro-Martin A, Cacicedo J, Ramos R, Guedea F: Stereotactic body radiotherapy for colorectal lung oligometastases: preliminary single-institution results. J BUON 2015;20:158-165.

27 Agolli L, Bracci S, Nicosia L, Valeriani M, De Sanctis V, Osti MF: Lung metastases treated with stereotactic ablative radiation therapy in oligometastatic colorectal cancer patients: outcomes and prognostic factors after long-term follow-up. Clin Colorectal Cancer 2016; DOI: 10.1016/j.clcc.2016.07.004.
28 van Laarhoven HW, Kaanders JH, Lok J, Peeters WJ, Rijken PF, Wiering B, Ruers TJ, Punt CJ, Heerschap A, van der Kogel AJ: Hypoxia in relation to vasculature and proliferation in liver metastases in patients with colorectal cancer. Int J Radiat Oncol Biol Phys 2006;64: 473-482.

29 Widder J, Klinkenberg TJ, Ubbels JF, Wiegman EM, Groen HJ, Langendijk JA: Pulmonary oligometastases: metastasectomy or stereotactic ablative radiotherapy? Radiother Oncol 2013;107:409-413.

30 Siva S, MacManus M, Ball D: Stereotactic radiotherapy for pulmonary oligometastases: a systematic review. J Thorac Oncol 2010;5:1091-1099.

31 Saltz LB: Metastatic colorectal cancer: is there one standard approach? Oncology (Williston Park) 2005; 19:1147-1154.

32 Rougier P, Milan C, Lazorthes F, Fourtanier G, Partensky C, Baumel H, Faivre J: Prospective study of prognostic factors in patients with unresected hepatic metastases from colorectal cancer. Fondation Française de Cancérologie Digestive. Br J Surg 1995;82:1397-1400.

33 Fong Y, Fortner J, Sun RL, Brennan MF, Blumgart LH: Clinical score for predicting recurrence after hepatic resection for metastatic colorectal cancer: analysis of 1001 consecutive cases. Ann Surg 1999;230:309-318.

34 Scheele J, Stang R, Altendorf-Hofmann A, Paul M: Resection of colorectal liver metastases. World J Surg 1995;19:59-71.

35 Nordlinger B, Guiguet M, Vaillant JC, Balladur P, Boudjema K, Bachellier P, Jaeck D: Surgical resection of colorectal carcinoma metastases to the liver. A prognostic scoring system to improve case selection, based on 1568 patients. Cancer 1996;77:1254-1262.

36 Pawlik TM, Scoggins CR, Zorzi D, Abdalla EK, Andres A, Eng C, Curley SA, Loyer EM, Muratore A, Mentha G, Capussotti L, Vauthey JN: Effect of surgical margin status on survival and site of recurrence after hepatic resection for colorectal metastases. Ann Surg 2005;241: 715-722, discussion 722-724.

37 Choti MA, Sitzmann JV, Tiburi MF, Sumetchotimetha W Rangsin R, Schulick RD, Lillemoe KD, Yeo CJ, Cameron JL: Trends in long-term survival following liver resection for hepatic colorectal metastases. Ann Surg 2002;235:759-766.

38 Aloia TA, Vauthey JN, Loyer EM, Ribero D, Pawlik TM, Wei SH, Curley SA, Zorzi D, Abdalla EK: Solitary colorectal liver metastasis: resection determines outcome. Arch Surg 2006;141:460-466.

39 Folprecht G, Grothey A, Alberts S, Raab HR, Köhne $\mathrm{CH}$ : Neoadjuvant treatment of unresectable colorectal liver metastases: correlation between tumour response and resection rates. Ann Oncol 2005;16:1311-1319.

40 Quan D, Gallinger S, Nhan C, Auer RA, Biagi JJ, Fletcher GG, Law CH, Moulton CA, Ruo L, Wei AC, McLeod RS; Surgical Oncology Program at Cancer Care Ontario: The role of liver resection for colorectal cancer metastases in an era of multimodality treatment: a systematic review. Surgery 2012;151:860-870.

41 Clancy C, Burke JP, Barry M, Kalady MF, Calvin Coffey J: A meta-analysis to determine the effect of primary tumor resection for stage IV colorectal cancer with unresectable metastases on patient survival. Ann Surg Oncol 2014;21:3900-3908.

42 Russell AH, Clyde C, Wasserman TH, Turner SS, Rotman M: Accelerated hyperfractionated hepatic irradiation in the management of patients with liver metastases: results of the RTOG dose escalating protocol. Int J Radiat Oncol Biol Phys 1993;27:117-123. 
43 Herfarth KK, Debus J, Lohr F, Bahner ML, Rhein B, Fritz P, Höss A, Schlegel W, Wannenmacher MF: Stereotactic single-dose radiation therapy of liver tumors: results of a phase I/II trial. J Clin Oncol 2001;19:164-170.

44 Wulf J, Guckenberger M, Haedinger U, Oppitz U, Mueller G, Baier K, Flentje M: Stereotactic radiotherapy of primary liver cancer and hepatic metastases. Acta Oncol 2006;45:838-847.

45 Méndez Romero A, Wunderink W, Hussain SM, De Pooter JA, Heijmen BJ, Nowak PC, Nuyttens JJ, Brandwijk RP, Verhoef C, Ijzermans JN, Levendag PC: Stereotactic body radiation therapy for primary and metastatic liver tumors: a single institution phase I-II study. Acta Oncol 2006;45:831-837.

46 Katz AW, Carey-Sampson M, Muhs AG, Milano MT, Schell MC, Okunieff P: Hypofractionated stereotactic body radiation therapy (SBRT) for limited hepatic metastases. Int J Radiat Oncol Biol Phys 2007;67:793-798.

47 Lee MT, Kim JJ, Dinniwell R, Brierley J, Lockwood G Wong R, Cummings B, Ringash J, Tse RV, Knox JJ, Dawson LA: Phase I study of individualized stereotactic body radiotherapy of liver metastases. J Clin Oncol 2009;27:1585-1591.

48 Rusthoven KE, Kavanagh BD, Cardenes H, Stieber VW, Burri SH, Feigenberg SJ, Chidel MA, Pugh TJ, Franklin W, Kane M, Gaspar LE, Schefter TE: Multiinstitutional phase I/II trial of stereotactic body radiation therapy for liver metastases. J Clin Oncol 2009;27: 1572-1578.

49 Vautravers-Dewas C, Dewas S, Bonodeau F, Adenis A Lacornerie T, Penel N, Lartigau E, Mirabel X: Imageguided robotic stereotactic body radiation therapy for liver metastases: is there a dose response relationship? Int J Radiat Oncol Biol Phys 2011;81:e39-47.

50 Rule W, Timmerman R, Tong L, Abdulrahman R, Meyer J, Boike T, Schwarz RE, Weatherall P, Chinsoo Cho L: Phase I dose-escalation study of stereotactic body radiotherapy in patients with hepatic metastases. Ann Surg Oncol 2011;18:1081-1087.

51 Scorsetti M, Comito T, Tozzi A, Navarria P, Fogliata A Clerici E, Mancosu P, Reggiori G, Rimassa L, Torzilli G, Tomatis S, Santoro A, Cozzi L: Final results of a phase II trial for stereotactic body radiation therapy for patients with inoperable liver metastases from colorectal cancer. J Cancer Res Clin Oncol 2015;141:543-553.

52 Goodman BD, Mannina EM, Althouse SK, Maluccio MA, Cárdenes HR: Long-term safety and efficacy of stereotactic body radiation therapy for hepatic oligometastases. Pract Radiat Oncol 2016;6:86-95.
53 Ahmed KA, Caudell JJ, El-Haddad G, Berglund AE, Welsh EA, Yue B, Hoffe SE, Naghavi AO, Abuodeh YA, Frakes JM, Eschrich SA, Torres-Roca JF: Radiosensitivity differences between liver metastases based on primary histology suggest implications for clinical outcomes after stereotactic body radiation therapy. Int J Radiat Oncol Biol Phys 2016;95:1399-1404.

54 Lee WS, Yun SH, Chun HK, Lee WY, Kim SJ, Choi SH, Heo JS, Joh JW, Choi D, Kim SH, Rhim H, Lim HK: Clinical outcomes of hepatic resection and radiofrequency ablation in patients with solitary colorectal liver metastasis. J Clin Gastroenterol 2008;42:945-949.

55 Mulier S, Ruers T, Jamart J, Michel L, Marchal G, Ni Y: Radiofrequency ablation versus resection for resectable colorectal liver metastases: time for a randomized trial? An update. Dig Surg 2008;25:445-460.

56 White RR, Avital I, Sofocleous CT, Brown KT, Brody LA, Covey A, Getrajdman GI, Jarnagin WR, Dematteo RP, Fong Y, Blumgart LH, D'Angelica M: Rates and patterns of recurrence for percutaneous radiofrequency ablation and open wedge resection for solitary colorectal liver metastasis. J Gastrointest Surg 2007;11: 256-263.

57 Bonnheim DC, Petrelli NJ, Herrera L, Walsh D, Mittelman A: Osseous metastases from colorectal carcinoma. Am J Surg 1986;151:457-459.

58 Katoh M, Unakami M, Hara M, Fukuchi S: Bone metastasis from colorectal cancer in autopsy cases. J Gastroenterol 1995;30:615-618.

59 Martenson JA Jr, Evans RG, Lie MR, Ilstrup DM, Dinapoli RP, Ebersold MJ, Earle JD: Treatment outcome and complications in patients treated for malignant epidural spinal cord compression (SCC). J Neurooncol 1985;3:77-84.

60 Barron KD, Hirano A, Araki S, Terry RD: Experiences with metastatic neoplasms involving the spinal cord. Neurology 1959;9:91-106.

61 Deschavanne PJ, Fertil B: A review of human cell radiosensitivity in vitro. Int J Radiat Oncol Biol Phys 1996; 34:251-266.

62 Malaise EP, Fertil B, Chavaudra N, Guichard M: Distribution of radiation sensitivities for human tumor cells of specific histological types: comparison of in vitro to in vivo data. Int J Radiat Oncol Biol Phys 1986; 12:617-624.

63 Gerszten PC, Mendel E, Yamada Y: Radiotherapy and radiosurgery for metastatic spine disease: what are the options, indications, and outcomes? Spine (Phila $\mathrm{Pa}$ 1976) 2009;34(suppl):S78-S92.
64 Rades D, Freundt K, Meyners T, Bajrovic A, Basic H, Karstens JH, Adamietz IA, Wildfang I, Rudat V, Schild SE, Dunst J: Dose escalation for metastatic spinal cord compression in patients with relatively radioresistan tumors. Int J Radiat Oncol Biol Phys 2011;80:14921497.

65 Chang EL, Shiu AS, Lii MF, Rhines LD, Mendel E, Mahajan A, Weinberg JS, Mathews LA, Brown BW, Maor $\mathrm{MH}$, Cox JD: Phase I clinical evaluation of near-simultaneous computed tomographic image-guided stereotactic body radiotherapy for spinal metastases. Int J Radiat Oncol Biol Phys 2004;59:1288-1294.

66 Yamada Y, Bilsky MH, Lovelock DM, Venkatraman ES, Toner S, Johnson J, Zatcky J, Zelefsky MJ, Fuks Z: High-dose, single-fraction image-guided intensitymodulated radiotherapy for metastatic spinal lesions. Int J Radiat Oncol Biol Phys 2008;71:484-490.

67 Amdur RJ, Bennett J, Olivier K, Wallace A, Morris CG Liu C, Mendenhall WM: A prospective, phase II study demonstrating the potential value and limitation of radiosurgery for spine metastases. Am J Clin Oncol 2009; 32:515-520.

68 Wang XS, Rhines LD, Shiu AS, Yang JN, Selek U, Gning I, Liu P, Allen PK, Azeem SS, Brown PD, Sharp HJ, Weksberg DC, Cleeland CS, Chang EL: Stereotactic body radiation therapy for management of spinal metastases in patients without spinal cord compression: a phase 1-2 trial. Lancet Oncol 2012;13:395-402.

69 Garg AK, Shiu AS, Yang J, Wang XS, Allen P, Brown BW, Grossman P, Frija EK, McAleer MF, Azeem S, Brown PD, Rhines LD, Chang EL: Phase 1/2 trial of single-session stereotactic body radiotherapy for previously unirradiated spinal metastases. Cancer 2012;118: 5069-5077.

70 Bilsky MH, Laufer I, Burch S: Shifting paradigms in the treatment of metastatic spine disease. Spine (Phila Pa 1976) 2009;34:22(suppl):S101-S107.

71 Patchell RA, Tibbs PA, Regine WF, Payne R, Saris S, Kryscio RJ, Mohiuddin M, Young B: Direct decompressive surgical resection in the treatment of spinal cord compression caused by metastatic cancer: a randomised trial. Lancet 2005;366:643-648.

72 Laufer I, Iorgulescu JB, Chapman T, Lis E, Shi W, Zhang Z, Cox BW, Yamada Y, Bilsky MH: Local disease control for spinal metastases following 'separation surgery' and adjuvant hypofractionated or high-dose single-fraction stereotactic radiosurgery: outcome analysis in 186 patients. J Neurosurg Spine 2013;18: 207-214. 